\title{
Comparative Effects of Organic Cocoa Shell-Based and Inorganic NPK Fertilization on the Growth and Yield of Four Cassava Varieties
}

\author{
Konan Kouakou Marius ${ }^{1}$, Kouamé N'guessan ${ }^{2}$, Kouassi Kouadio Ignace ${ }^{3}$, \\ Koffi Kouamé Kévin', Kouamé Kouassi2, \\ Zoro Bi Irié Arsène1, Dogbo Dénézon Odette ${ }^{1}$
}

\begin{abstract}
${ }^{1}$ Plant Production Research Unit, Department of Natural Sciences, University Nangui Abrogoua, Abidjan, Côte d'Ivoire ${ }^{2}$ Improvement of Crop Production, Department of Agroforestry, University Jean Lorougnon Guédé, Daloa, Côte d'Ivoire ${ }^{3}$ Ecology and Biodiversity Research Unit, Department of Natural Sciences, University Nangui Abrogoua, Abidjan, Côte d'Ivoire

Email: ^maximekouamelma@yahoo.fr
\end{abstract}

How to cite this paper: Marius, K.K., N'guessan, K., Ignace, K.K., Kévin, K.K., Kouassi, K., Arsène, Z.B.I. and Odette, D.D. (2020) Comparative Effects of Organic Cocoa Shell-Based and Inorganic NPK Fertilization on the Growth and Yield of Four Cassava Varieties. Open Journal of Soil Science, 10, 217-232.

https://doi.org/10.4236/ojss.2020.106011

Received: May 6, 2020

Accepted: June 2, 2020

Published: June 5, 2020

Copyright (c) 2020 by author(s) and Scientific Research Publishing Inc. This work is licensed under the Creative Commons Attribution International License (CC BY 4.0).

http://creativecommons.org/licenses/by/4.0/ (c) (i) Open Access

\begin{abstract}
Looking of finding an alternative to the use of chemical fertilizers to increase yields of cassava (Manihot esculenta), trials were carried out in the Lamto zone in central Côte d'Ivoire. Thus, the effects of compost and ash from cocoa shell and NPK were tested on the agronomic parameters of cassava. The trial was conducted for two years with four varieties of cassava: Yacé, Alleda agba, Six mois and Bonoua, grown on elementary plots treated with one of these fertilizers. The experimental design was complete randomized blocks with three replicates. Analysis of the results showed that the Six mois variety gave the longest stems $(131,67 \mathrm{~cm})$ with the cocoa shell compost. The Bonoua variety, on the other hand, gave the largest diameter of the stem base (21.56 $\mathrm{mm})$, a higher number of leaves (77.30) and a large wingspan $(136.89 \mathrm{~cm})$ with cocoa shell compost. The leaves developed by the plants of this variety were wider $(19.30 \mathrm{~cm})$ and longer $(17.96 \mathrm{~cm})$ with cocoa shell compost. Also, this Bonoua variety treated with shell compost yielded a high number of tuberized roots (5.11), high average weight per plant $(5.83 \mathrm{~kg} / \mathrm{plant})$ and higher yield ( $58.29 \mathrm{t} / \mathrm{ha})$. This compost of cocoa shell has also allowed a better conservation of the cultivated soils quality.
\end{abstract}

\section{Keywords}

Cocoa Shell Ash, Cocoa Shell Compost, Cassava Variety, Growth, Yield 


\section{Introduction}

The cultivation of cassava (Manihot esculenta Crantz) is widely spread in the tropical and subtropical belt of the globe where it occupies an important place in the diet of populations [1]. Global cassava production in 2016 was estimated at 292 million tons, of which 178 million tons were produced in Africa [2]. Cassava is generally grown by low-income farmers, especially women, on marginal lands. For these farmers and their families, it is an important crop because it contributes to food security and generates substantial income [3].

In recent years, cassava has achieved industrial crop status in Côte d'Ivoire. It is the second most important food crop after yam [4]. It is now grown on a large scale, repeatedly season after season, on the same plot of land. This leads to soil impoverishment and lower yields [5] [6]. In order to improve cassava production and access to planting material, new high-yielding cassava varieties, developed through research, have been made available to cassava farmers. These varieties are resistant to diseases and pests and can produce up to 40 tons per hectare per year, compared to less than 20 tons per hectare for traditional cassava varieties [7]. Despite the introduction of these improved varieties, cassava yields vary between 20 and 30 tons per hectare, which is still far below the potential yield.

Thus, in order to improve their yields, producers practice numerous cultivation techniques such as crop rotation, crop rotation or burying organic, plant or animal residues in the soil [8]. These organic amendments remain one of the cost-effective options to support long-term improvements in agricultural productivity [9] [10] [11]. Thus, the use of household waste, animal excreta, sewage sludge but also agricultural residues should be supported [12]. Unfortunately, these wastes are not always used in agriculture but are abandoned on the spot in the production areas. In cities, this waste is often dumped in ravines for the most part, thus contributing to urban environmental pollution [11]. This is the case of cocoa shells, which are organic residues available in significant quantities in cocoa farms.

Indeed, Côte d'Ivoire, the world's largest cocoa producer, produces each year about 4,000,000 tons of cocoa shells available on plantations and which are not valorized [13]. These tons of shells remain and decompose at the denting site. It would therefore make sense to add value to these agricultural by-products by using them for the production of organic fertilizers to help improve soil fertility.

The objective of this work was to assess the influence of compost and ash from cocoa shell on the agronomic parameters of cassava. The specific objectives consisted in: 1) producing cocoa shell-based compost and ash and determining their chemical compositions, 2) measuring the effect of these different fertilizers and that of NPK taken as a reference, on some agronomic parameters of cassava growth and yield.

\section{Materials and Methods}

\subsection{Study Site}

The tests were carried out in a farming environment in the "Lamto" area. It is 
located in the center of Côte d'Ivoire, in the southern tip of the "V-Baoulé". It is a contact zone between the savannah of the North and the forest of the South which draws a V-shaped indentation. It is located $159 \mathrm{Km}$ from the city of Abidjan between $6^{\circ} 25^{\prime}$ to $6^{\circ} 13^{\prime}$ North latitudes and $5^{\circ} 02^{\prime}$ to $4^{\circ} 97^{\prime}$ West longitudes. The climate is of humid tropical type with four seasons. The main rainy season is between March and July with a peak of $266.50 \mathrm{~mm}$ of rain in June 2017. The small rainy season is from September to November with $94.40 \mathrm{~mm}$ of rain in November 2017. The long dry season is from December to February with a maximum temperature of $30.59^{\circ} \mathrm{C}$ in February. In addition, the short dry season lasted one month (August), with $34.94^{\circ} \mathrm{C}$. The soils are of ferralitic types and their $\mathrm{pH}$ varies from 5 to 6.5 [14].

\subsection{Plant Material and Fertilizer}

The plant material used consisted of four traditional varieties of cassava locally known as Yacé, Alleda agba, Six mois and Bonoua. They all have a cultivation cycle of 12 months and were collected from farmers in Aheremou II, a village located in the study area. The Yacé and Alleda agba varieties are singlestemmed, the Six mois variety has its stem with dichotomous branching while

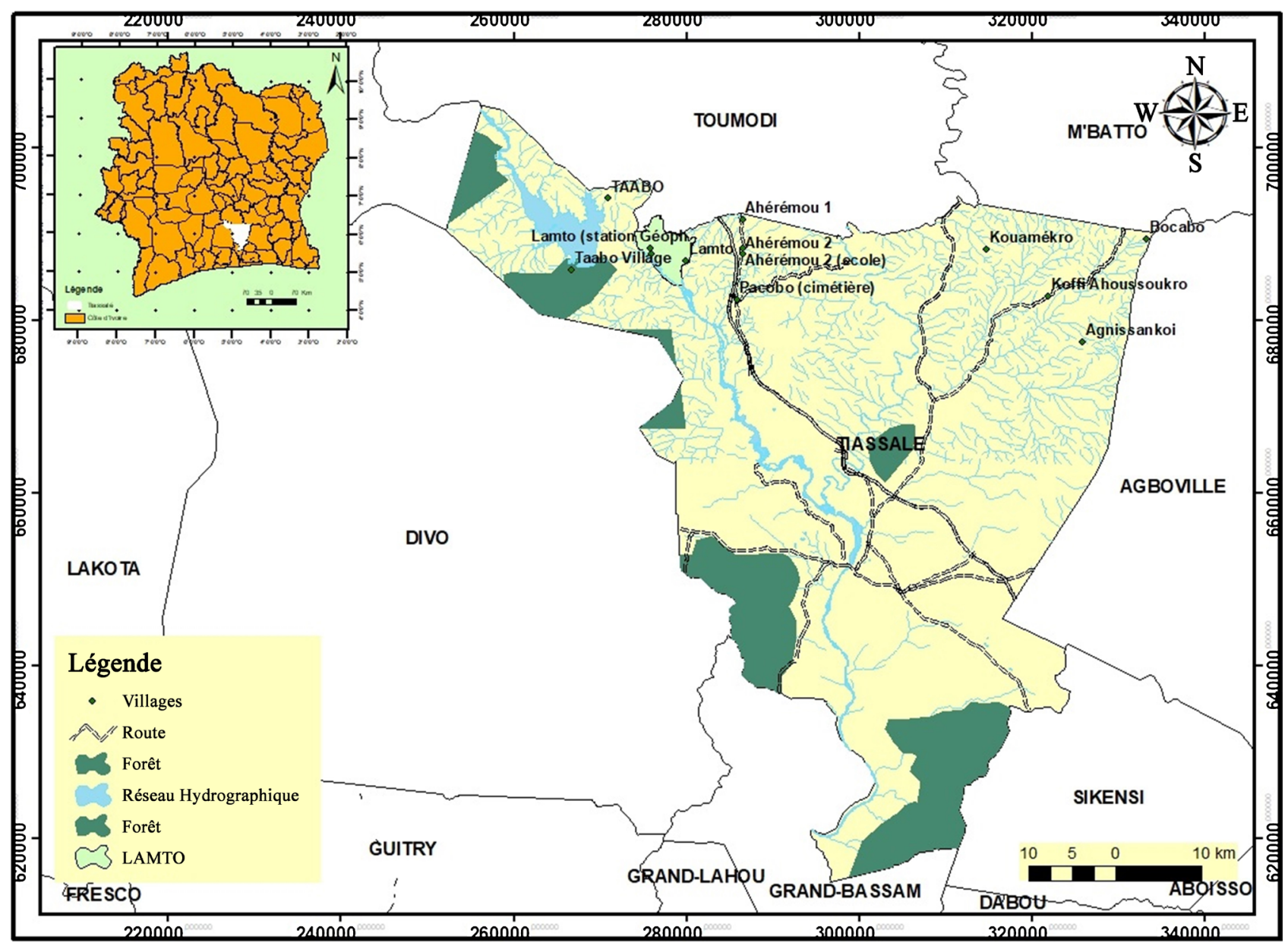

Figure 1. Geographical location of the study site. 
the Bonoua variety has its stem with trichotomous branching. Healthy stems of these four cassava varieties were selected from plants at least six months old. Cuttings of 20 to $25 \mathrm{~cm}$ with four to six nodes were cut with pruning shears, avoiding soft parts of the stem [15].

The fertilizer material consisted of compost made from cocoa pod shells $(\mathrm{N}$ : $\left.7.50 \mathrm{~g} \cdot \mathrm{kg}^{-1}, \mathrm{P}: 2.30 \mathrm{~g} \cdot \mathrm{kg}^{-1}, \mathrm{P}: 10.19 \mathrm{~g} \cdot \mathrm{kg}^{-1}\right)$, ash from dried cocoa pod shell N:4,50 $\mathrm{g} \cdot \mathrm{kg}^{-1}, \mathrm{P}: 3.80 \mathrm{~g} \cdot \mathrm{kg}^{-1}$, P: $75.91 \mathrm{~g} \cdot \mathrm{kg}^{-1}$ ) and the chemical fertilizer NPK 12-22-22 $\left(\mathrm{N}, \mathrm{P}\right.$ et $\mathrm{K}: 48 \mathrm{~kg}, 88 \mathrm{~kg}$ et $\left.88 \mathrm{~kg} \cdot \mathrm{ha}^{-1}\right)$.

\subsection{Preparation of Compost and Cocoa Ash}

For the preparation of the cocoa shell compost, a pit $(1 \mathrm{~m} \times 1 \mathrm{~m} \times 1 \mathrm{~m})$ was dug and the bottom was cemented to prevent loss of nutrients. The cocoa shells were collected in the study area from a cocoa farmer. The pit was filled with $50 \mathrm{~kg}$ of dried shells and $5 \mathrm{~kg}$ of Acacia mangium leaves sorted and weighed for composting. The contents of the pit were turned over several times using the "Indore Method" [16]. The moisture content of the pit was regularly adjusted to keep it between $50 \%-60 \%$. The pit was covered with oil palm leaves (Elaeis guineensis Jacq) to maintain humidity. The compost matured for three months. The compost matured for three months.

To prepare the ash, the cocoa pod shells were dried, sorted and weighed. Fifty (50) $\mathrm{kg}$ of dried cocoa pod shells were burnt and the ash obtained was collected.

\subsection{Collection and Preparation of Samples of Soil, Compost and Ash from Cocoa Shells}

Soil samples were taken from the experimental site at a depth of $0-30 \mathrm{~cm}$ before planting the cuttings and after the cassava harvest. Soil samples were taken from different parts of the plot. These samples were air-screened, crushed and well homogenized, sieved with a $2 \mathrm{~mm}$ sieve and a sub-sample was taken for analysis. At the end of the production of the different fertilizers, one kilogram $(1 \mathrm{~kg})$ of each organic fertilizer was taken and analyzed at the Laboratory of Plant and Soil Analysis (LPSA) of the Graduate School of Agronomy (GSA) of the Institute National Polytechnique Houphouet-Boigny (INP-HB) of Yamoussoukro, Côte d'Ivoire. The mineral content was expressed $\left(\mathrm{g} \cdot \mathrm{kg}^{-1}\right)$ in relation to the quantity of dry matter in the sample for elements $\mathrm{C}, \mathrm{N}, \mathrm{P}, \mathrm{K}, \mathrm{Mg}$ and $\mathrm{Ca}$. The results were used to calculate the ratios of carbon and nitrogen $(\mathrm{C} / \mathrm{N})$. Also, cation exchange capacity (CEC) of the soil which is the maximum amount of cation that a soil can absorb (per $100 \mathrm{~g}$ of dry matter). It is determined by the Metson method described in the NF X31-130 standard [17].

\subsection{Experimental Design}

The experimental design used for this study was a complete randomized block design with 3 replicates. Each block consisted of twelve treatment and four control subplots. One treatment corresponded to a cassava variety whose crop soil 
was fertilized with a type of fertilizer. A total of four varieties of cassava $\times$ three different fertilizers were tested. Each subplot had a size of $4 \mathrm{~m} \times 3 \mathrm{~m}$ or $12 \mathrm{~m}^{2}$ and two consecutive subplots were separated by a $2 \mathrm{~m}$ wide bare band that was regularly weeded. The distance between the sowing points of the cassava cuttings was $1 \mathrm{~m} \times 1 \mathrm{~m}$, i.e. 10,000 plants $\mathrm{ha}^{-1}$. A repetition of subplot corresponds to three rows of 4 plants each, resulting in a total of 12 plants of cassava per subplot. All the seedlings were sown on the same day at the rate of one cutting per hole and at a depth of 2 to $3 \mathrm{~cm}$. The trial was set up on a plot with a total area of $1200 \mathrm{~m}^{2}(20 \mathrm{~m} \times 60 \mathrm{~m})$ with a $3 \mathrm{~m}$ wide border.

Fertilizer was applied around the cassava plants within a radius of $10 \mathrm{~cm}, 2$ weeks after sowing. Fertilizer application was carried out on the same day at a single dose of $40 \mathrm{~g} \cdot$ plant $^{-1}$, i.e. $400 \mathrm{~kg} \cdot \mathrm{ha}^{-1}$ for NPK (48 kg.ha ${ }^{-1}$ of N, $88 \mathrm{~kg}$. ha $\mathrm{ha}^{-1}$ and $88 \mathrm{~kg} \cdot \mathrm{ha}^{-1}$ ) and $1 \mathrm{~kg}$. plant ${ }^{-1}$ or $10 \mathrm{t} \cdot \mathrm{ha}^{-1}$ for cocoa compost shells (N: 7.50 $\left.\mathrm{g} \cdot \mathrm{kg}^{-1}, \mathrm{P}: 2.30 \mathrm{~g} \cdot \mathrm{kg}^{-1}, \mathrm{P}: 10.19 \mathrm{~g} \cdot \mathrm{kg}^{-1}\right)$, and cocoa ash $\left(\mathrm{N}: 4.50 \mathrm{~g} \cdot \mathrm{kg}^{-1}, \mathrm{P}: 3.80\right.$ $\left.\mathrm{g} \cdot \mathrm{kg}^{-1}, \mathrm{P}: 75.91 \mathrm{~g} \cdot \mathrm{kg}^{-1}\right)$. The trials were carried out from March to December 2017 for the first season and from March to December 2018 for the second season. Weeds were controlled by regular hand weeding to avoid competition with cassava.

\subsection{Agronomic Parameters Measured}

Eleven agronomic parameters selected from cassava descriptors (Fukuda et al. [18], were examined in this study. There are: the number of stems from the same cutting (NSC), the number of leaves per plant (NLP) was determined by multiplying the number of apexes per plant by the average number of leaves per apex according to the methodology adopted by Daellenbach et al. [19]. Then the length (LL) and average width (LW) of the leaf and the wingspan of the foliage (WIN) were also measured. Finally, mean diameter at the stem base (DSB) and mean total stem length (TSL) were determined for the most developed stem of the plant. The measurement methodology followed that described by Ambang et al. [20]. At harvest, four performance parameters were measured. Plants were uprooted and the mean number of tuberized roots (NTRP), mean tuberized root weight (W1TRP) and tuberized root weight per plant (WTRP) were recorded. The measurement methodology followed that described by Aniekwe et al. [21]. Finally, the fresh yield per hectare (Y) was calculated. It was estimated by multiplying the average weight of tuberized roots per plant by the number of plants calculated for 1 ha, i.e. 10,000 plants. These plants were harvested 10 months after planting according to the approach of Lenis et al. [22]. Observations were made on 10 plants in each elementary plot.

\subsection{Data Analysis}

A multivariate variance analysis (MVA) was performed with $\mathrm{R}$ software, version 3.1. The AMOVAs were supplemented by ANOVA tests when interactions were significant. When a significant difference is observed between the different fac- 
tors, Least Significant Difference (LSD) multiple range-tests procedure were used to separate the means of the different treatments. Means were given as mean followed by standard deviation $(\mathrm{M} \pm \mathrm{SD})$. Significant differences were determined at $\mathrm{P} \leq 0.05$.

\section{Results and Discussion}

\subsection{Results}

\subsubsection{Chemical Parameters of Organic Residues}

Table 1 presents data on the chemical characteristics of each organic fertilizer. Analyses showed that the levels of carbon $\left(387.70 \mathrm{~g} \cdot \mathrm{kg}^{-1}\right)$ and nitrogen $(7.50$ $\left.\mathrm{g} \cdot \mathrm{kg}^{-1}\right)$ were higher in cocoa shells compost than in cocoa shells ash. On the other hand, the levels of phosphorus $\left(3.80 \mathrm{~g} \cdot \mathrm{kg}^{-1}\right)$, potassium $\left(75.91 \mathrm{~g} \cdot \mathrm{kg}^{-1}\right)$, calcium $\left(59.87 \mathrm{~g} \cdot \mathrm{kg}^{-1}\right)$ and magnesium $\left(5.17 \mathrm{~g} \cdot \mathrm{kg}^{-1}\right)$ were higher in cocoa shells ash than in cocoa shells compost.

\subsubsection{Physico-Chemical Parameters of the Test Soils}

The results of the pre- and post-cultivation soil laboratory analyses are shown in Table 2. Reading this table shows that the $\mathrm{pH}$ of the crop soils after tuberous root harvest is slightly acidic (6.30 - 7.30). The carbon $\left(19.70 \mathrm{~g} \cdot \mathrm{kg}^{-1}\right)$ and total nitrogen $\left(1.80 \mathrm{~g} \cdot \mathrm{kg}^{-1}\right)$ contents are higher in the cocoa shells compost plots. Also, the levels of organic matter $\left(33.90 \mathrm{~g} \cdot \mathrm{kg}^{-1}\right)$ and exchangeable phosphorus (66 - 77 $\mathrm{ppm}$ ) are higher in soils where cocoa shells compost has been incorporated. Cation exchange capacity (CEC) and exchangeable bases concentrations in the fertilized soils were higher compared to the control. However, the highest values were observed in soils where cocoa shells compost was applied (CEC $=12.44$ $\mathrm{Cmol} \cdot \mathrm{kg}^{-1}, \mathrm{Ca}^{2+}=3.82 \mathrm{Cmol} \cdot \mathrm{kg}^{-1}, \mathrm{Mg}^{2+}=1.73 \mathrm{Cmol} \cdot \mathrm{kg}^{-1}, \mathrm{~K}^{+}=0.14 \mathrm{Cmol} \cdot \mathrm{kg}^{-1}$; $\left.\mathrm{Na}^{+}=0.08 \mathrm{Cmol} \cdot \mathrm{kg}^{-1}\right)$.

\subsubsection{Overall Effect of the Different Factors and Their Interactions on the Agronomic Parameters of Cassava Growth}

The results of the multivariate analysis of variance (AMOVA) showed that the treatments, varieties and their interactions (treatments $\times$ varieties) had a significant positive effect on the agronomic parameters of cassava $(\mathrm{P}<0.001)$. However, as interactions were important, interpretations were made only with the interaction table (ANOVA II). Thus, for a better presentation of the results, a first table of the double interaction will be made for the growth parameters and a

Table 1. Chemical composition of organic residues.

\begin{tabular}{cccccccc}
\hline \multirow{7}{*}{$\begin{array}{c}\text { Organic } \\
\text { residues }\end{array}$} & $\mathrm{C}\left(\mathrm{g} \cdot \mathrm{kg}^{-1}\right)$ & $\begin{array}{c}\mathrm{N} \\
\left(\mathrm{g} \cdot \mathrm{kg}^{-1}\right)\end{array}$ & $\mathrm{P}\left(\mathrm{g} \cdot \mathrm{kg}^{-1}\right)$ & $\mathrm{K}\left(\mathrm{g} \cdot \mathrm{kg}^{-1}\right)$ & $\mathrm{Ca}\left(\mathrm{g} \cdot \mathrm{kg}^{-1}\right)$ & $\begin{array}{c}\mathrm{Mg} \\
\left(\mathrm{g} \cdot \mathrm{kg}^{-1}\right)\end{array}$ & $\mathrm{C} / \mathrm{N}$ \\
\hline $\begin{array}{c}\text { Cocoa shell ash } \\
\begin{array}{c}\text { Compost of } \\
\text { cocoa shells }\end{array}\end{array}$ & 129.20 & 4.50 & 3.80 & 75.91 & 59.87 & 5.17 & 28.71 \\
\hline
\end{tabular}


Table 2. Physical and chemical composition of the soils of the different sub-plots.

\begin{tabular}{|c|c|c|c|c|c|c|c|c|c|c|c|}
\hline \multirow{2}{*}{ Treatments } & \multirow{2}{*}{$\begin{array}{c}\mathrm{pH} \\
\text { water }\end{array}$} & C & $\mathrm{Nt}$ & & & \multirow{2}{*}{$\begin{array}{c}\text { P.ass } \\
(\mathrm{ppm})\end{array}$} & \multicolumn{5}{|c|}{ Absorbent Complex $\left(\mathrm{Cmol} \cdot \mathrm{kg}^{-1}\right)$} \\
\hline & & $\left(g \cdot \mathrm{kg}^{-1}\right)$ & $\left(g \cdot \mathrm{kg}^{-1}\right)$ & & $\mathrm{H} M$ (g.kg & & CEC & $\mathrm{Ca}^{2+}$ & $\mathrm{Mg}^{2+}$ & $\mathrm{K}^{+}$ & $\mathrm{Na}^{+}$ \\
\hline IS & 6.10 & 14.40 & 1.30 & 11 & 24.80 & 42 & 6.18 & 1.68 & 0.97 & 0.09 & 0.06 \\
\hline YcCo & 6.40 & 16.80 & 1.50 & 11 & 21.90 & 37 & 6.40 & 1.87 & 1.03 & 0.10 & 0.03 \\
\hline $\mathrm{AaCo}$ & 6.30 & 16.70 & 1.50 & 11 & 21.60 & 36 & 6.21 & 1.76 & 0.93 & 0.10 & 0.03 \\
\hline SmCo & 6.40 & 16.50 & 1.50 & 11 & 21.70 & 37 & 6.19 & 1.88 & 0.94 & 0.10 & 0.03 \\
\hline BoCo & 6.30 & 16.70 & 1.60 & 11 & 21.50 & 38 & 6.14 & 1.68 & 0.86 & 0.10 & 0.04 \\
\hline YcNPK & 6.60 & 15.20 & 1.40 & 11 & 26.20 & 73 & 6.66 & 2.26 & 1.16 & 0.11 & 0.04 \\
\hline AaNPK & 6.40 & 14.50 & 1.30 & 11 & 24.30 & 65 & 6.14 & 1.89 & 0.88 & 0.09 & 0.03 \\
\hline SmNPK & 6.60 & 13.40 & 1.30 & 11 & 24.80 & 54 & 6.47 & 1.97 & 1.08 & 0.09 & 0.03 \\
\hline BoNPK & 6.50 & 14.40 & 1.40 & 11 & 25.20 & 56 & 6.26 & 2.16 & 0.95 & 0.09 & 0.03 \\
\hline YcCSA & 6.40 & 14.00 & 1.30 & 11 & 24.10 & 50 & 6.87 & 1.74 & 1.38 & 0.09 & 0.03 \\
\hline $\mathrm{AaCSA}$ & 6.10 & 14.40 & 1.40 & 10 & 24.80 & 48 & 6.90 & 1.92 & 1.28 & 0.11 & 0.04 \\
\hline SmCSA & 6.80 & 17.00 & 1.60 & 11 & 29.20 & 46 & 6.87 & 2.12 & 0.94 & 0.07 & 0.03 \\
\hline BoCSA & 6.60 & 13.30 & 1.20 & 11 & 22.80 & 47 & 6.40 & 1.67 & 0.53 & 0.09 & 0.06 \\
\hline YcCSC & 6.90 & 19.30 & 1.60 & 12 & 33.20 & 77 & 8.37 & 2.49 & 1.73 & 0.13 & 0.04 \\
\hline $\mathrm{AaCSC}$ & 6.30 & 19.70 & 1.80 & 11 & 33.90 & 66 & 8.58 & 2.29 & 1.54 & 0.12 & 0.04 \\
\hline SmCSC & 7.30 & 17.60 & 1.50 & 12 & 30.20 & 68 & 12.44 & 3.82 & 1.13 & 0.10 & 0.03 \\
\hline BoCsC & 6.90 & 18.50 & 1.50 & 12 & 31.90 & 77 & 11.22 & 3.52 & 1.47 & 0.14 & 0.08 \\
\hline
\end{tabular}

$\mathrm{Nt}$ t total nitrogen, MO: organic matter, P. ass: assimilable phosphorus, CEC: cation exchange capacity, IS: initial soil, Yc: Yace, Aa: Alleda agba, Sm: Six mois, Bo: Bonoua, CSC: cocoa shells compost, CSA: cocoa shells ash, NPK: chemical fertilizer, Co: Control.

second one for the yield parameters.

\subsubsection{Effect of Treatment and Variety on the Agronomic Parameters of Cassava Growth}

Table 3 presents the results of the effect of the "fertilizer-variety interaction" on cassava growth parameters. The analysis of the table shows that this interaction positively influences $(\mathrm{P}<0.001)$ the cassava growth parameters except the number of stems per cutting $(P=0.16)$. This number of stems remained constant during the different life stages of the plant (2.89). Stem length varied from $131.67 \mathrm{~cm}$ to $61.27 \mathrm{~cm}$ depending on the cassava variety and fertilizer. The Six mois variety produced the longest stems. It was followed by the Alleda agba variety, then the Yacévariety and finally the Bonoua variety, regardless of the fertilizer used. The longest lengths were obtained with cocoa shells compost (131.67 $\mathrm{cm})$. Moreover, there is no difference in the growth of the stems of plants fertilized with cocoa shells ash or NPK. With a value of $61.27 \mathrm{~cm}$, the untreated Bonoua variety gave the shortest stems. As regards the diameter at the stem base, it varies from $21.58 \mathrm{~mm}$ to $11.35 \mathrm{~mm}$ depending on the fertilizer applied to the crop soil. Contrary to the length of the stem, observations have shown that the 
Table 3. Effect of treatments and variety on cassava growth parameters.

\begin{tabular}{|c|c|c|c|c|c|c|c|c|}
\hline Treatments & Varieties & NSC & $\operatorname{TLS}(\mathrm{cm})$ & DSB (mm) & NLP & $\mathrm{LL}(\mathrm{cm})$ & $\mathrm{LW}(\mathrm{cm})$ & WIN (cm) \\
\hline \multirow[t]{4}{*}{ Co } & Yc & $2.33 \pm 1.19$ & $68.23 \pm 49.33^{j}$ & $11.35 \pm 4.35^{\mathrm{h}}$ & $31.59 \pm 21.48^{\mathrm{f}}$ & $13.14 \pm 3.78^{\mathrm{e}}$ & $11.62 \pm 2.42^{\mathrm{f}}$ & $62.78 \pm 21.96^{\mathrm{k}}$ \\
\hline & $\mathrm{Aa}$ & $2.33 \pm 0.98$ & $67.49 \pm 45.81^{j}$ & $11.35 \pm 4.61^{\mathrm{h}}$ & $32.67 \pm 22.94^{\mathrm{ef}}$ & $13.94 \pm 4.81^{\mathrm{de}}$ & $12.14 \pm 2.41^{\mathrm{e}}$ & $65.60 \pm 25.18^{j}$ \\
\hline & $\mathrm{Sm}$ & $2.48 \pm 1.22$ & $70.05 \pm 52.64^{\mathrm{i}}$ & $11.53 \pm 3.87^{\mathrm{h}}$ & $30.21 \pm 18.02^{\mathrm{f}}$ & $13.62 \pm 2.15^{\mathrm{e}}$ & $12.43 \pm 1.27^{\mathrm{e}}$ & $66.17 \pm 13.77^{j}$ \\
\hline & Bo & $2.85 \pm 0.91$ & $61.27 \pm 45.65^{\mathrm{k}}$ & $12.35 \pm 6.15^{\mathrm{g}}$ & $33.42 \pm 25.59^{\mathrm{e}}$ & $14.65 \pm 4.71^{\mathrm{d}}$ & $14.13 \pm 4.74^{\mathrm{c}}$ & $69.66 \pm 32.26^{\mathrm{i}}$ \\
\hline \multirow[t]{4}{*}{ NPK } & Yc & $2.15 \pm 0.96$ & $76.23 \pm 62.37^{\mathrm{f}}$ & $13.20 \pm 7.54^{\mathrm{g}}$ & $33.17 \pm 24.19^{\mathrm{e}}$ & $13.80 \pm 5.11^{\mathrm{de}}$ & $13.44 \pm 4.67^{\mathrm{d}}$ & $75.82 \pm 33.67^{\mathrm{fg}}$ \\
\hline & $\mathrm{Aa}$ & $2.47 \pm 0.86$ & $96.89 \pm 56.45^{\mathrm{d}}$ & $12.83 \pm 3.37^{\mathrm{f}}$ & $38.57 \pm 19.20^{\mathrm{d}}$ & $16.47 \pm 4.72^{\mathrm{b}}$ & $15.18 \pm 3.72^{\mathrm{b}}$ & $77.64 \pm 20.05^{f}$ \\
\hline & $\mathrm{Sm}$ & $2.49 \pm 0.90$ & $124.94 \pm 66.40^{\mathrm{b}}$ & $13.94 \pm 4.65^{\mathrm{e}}$ & $44.99 \pm 24.26^{c}$ & $16.85 \pm 4.39^{\mathrm{b}}$ & $15.36 \pm 2.84^{\mathrm{b}}$ & $82.81 \pm 25.43^{\mathrm{de}}$ \\
\hline & Bo & $2.82 \pm 0.75$ & $73.56 \pm 57.52^{\mathrm{h}}$ & $14.48 \pm 8.15^{\mathrm{d}}$ & $48.77 \pm 29.15^{\mathrm{b}}$ & $15.42 \pm 4.34^{\mathrm{c}}$ & $15.58 \pm 4.52^{\mathrm{b}}$ & $87.89 \pm 44.37^{\mathrm{c}}$ \\
\hline \multirow[t]{4}{*}{ CSA } & Yc & $2.52 \pm 0.89$ & $75.03 \pm 36.77^{\mathrm{f}}$ & $12.04 \pm 6.74^{\mathrm{g}}$ & $34.21 \pm 21.53^{\mathrm{e}}$ & $13.51 \pm 4.26^{\mathrm{e}}$ & $13.08 \pm 3.13^{\mathrm{d}}$ & $72.74 \pm 31.60^{\mathrm{h}}$ \\
\hline & $\mathrm{Aa}$ & $2.89 \pm 1.07$ & $95.81 \pm 43.73^{\mathrm{d}}$ & $12.33 \pm 7.71^{\mathrm{g}}$ & $35.07 \pm 18.27^{\mathrm{de}}$ & $14.36 \pm 3.28^{\mathrm{d}}$ & $14.47 \pm 2.57^{c}$ & $74.74 \pm 14.99^{g h}$ \\
\hline & $\mathrm{Sm}$ & $2.94 \pm 1.07$ & $105.73 \pm 50.85^{c}$ & $12.89 \pm 5.93^{\mathrm{f}}$ & $43.31 \pm 32.08^{c}$ & $15.66 \pm 3.03^{c}$ & $15.52 \pm 2.57^{\mathrm{b}}$ & $80.80 \pm 26.67^{\mathrm{e}}$ \\
\hline & Bo & $2.88 \pm 0.82$ & $73.41 \pm 54.48^{\mathrm{h}}$ & $14.33 \pm 8.16^{\mathrm{d}}$ & $47.34 \pm 32.73^{b}$ & $15.52 \pm 2.50^{c}$ & $15.67 \pm 2.67^{\mathrm{b}}$ & $88.30 \pm 55.41^{c}$ \\
\hline \multirow[t]{4}{*}{$\mathrm{CSC}$} & Yc & $2.31 \pm 1.01$ & $79.66 \pm 59,90^{\mathrm{e}}$ & $13.81 \pm 6.78^{\mathrm{e}}$ & $38.09 \pm 26.21^{\mathrm{d}}$ & $15.07 \pm 4.48^{\mathrm{c}}$ & $14.47 \pm 3.70^{c}$ & $82.99 \pm 35.33^{\mathrm{de}}$ \\
\hline & $\mathrm{Aa}$ & $2.43 \pm 0.97$ & $106.51 \pm 64.60^{c}$ & $15.61 \pm 6.39^{c}$ & $44.23 \pm 30.80^{c}$ & $16.23 \pm 4.51^{\mathrm{b}}$ & $15.14 \pm 3.68^{\mathrm{ab}}$ & $85.31 \pm 27.55^{\mathrm{cd}}$ \\
\hline & $\mathrm{Sm}$ & $2.76 \pm 0.96$ & $131.67 \pm 66.46^{\mathrm{a}}$ & $16.53 \pm 5.54^{\mathrm{b}}$ & $47.82 \pm 28.59^{\mathrm{b}}$ & $16.93 \pm 3.16^{\mathrm{b}}$ & $15.32 \pm 2.87^{\mathrm{ab}}$ & $90.00 \pm 15.30^{\mathrm{b}}$ \\
\hline & Bo & $2.99 \pm 0.79$ & $74.36 \pm 46.80^{g}$ & $21.58 \pm 8.68^{\mathrm{a}}$ & $77.30 \pm 47.52^{\mathrm{a}}$ & $17.96 \pm 3.18^{\mathrm{a}}$ & $19.30 \pm .2 .24^{\mathrm{a}}$ & $136.89 \pm 88.19^{\mathrm{a}}$ \\
\hline $\mathrm{F}$ & & 1.45 & 3.56 & 3.62 & 6.05 & 2.49 & 3.13 & 4.71 \\
\hline $\mathrm{P}$ & & 0.16 & $<0.001$ & $<0.001$ & $<0.001$ & $<0.001$ & $<0.001$ & $<0.001$ \\
\hline
\end{tabular}

NB. For each parameter, the means followed by different letters are statistically different when $\mathrm{P}<0.05$. NSC: number of stems per cutting, TLS: total length of main stem, LW: leaf width, LL: leaf length, NLP: number of leaves, WIN: wingspan of foliage, DSB: diameter at the stem base, CSC: cocoa shells compost, CSA: cocoa shells ash, Co: Control, Yc: Yacé, Bo: Bonoua, Sm: Six mois, Aa: Alleda agba, NPK: chemical fertilizer.

stems of large diameters were obtained with the Bonoua variety fertilized with cocoa shells compost. Reading the table reveals that the plants from the fertilized sub-plots induced more leaves compared to the control plants. However, the Bonoua variety with trichotomous branching developed the highest number of leaves $(77.30)$ and a wider leaf span $(136.89 \mathrm{~cm})$. Similarly, the leaves developed by the plants on the cocoa shell compost plots gave wider $(19.30 \mathrm{~cm})$ and longer $(17.96 \mathrm{~cm})$ leaf blades.

\subsubsection{Effect of the Interaction of Fertilizers, Varieties on Cassava Yield Parameters}

Table 4 shows the results of the effect of variety treatment interaction on cassava yield parameters. Reading the table reveals that there is a difference in the effect of the two factors on these yield parameters. Indeed, plants from the fertilized plots produced a higher average number of tuberized roots per plant than those from the untreated plots. Thus, the Bonoua and Six mois varieties harvested from the fertilized plots produced the highest average number of tuberous roots per plant (5.11) compared to Alleda agba and Yacé(3.50). The average weight of one tuberous root per plant at harvest from the cocoa shells compost plots was 
Table 4. Effect of treatments and variety on cassava yield parameters.

\begin{tabular}{|c|c|c|c|c|c|}
\hline \multirow[b]{2}{*}{ Treatments } & \multirow[b]{2}{*}{ Varieties } & \multicolumn{4}{|c|}{ Performance Parameters } \\
\hline & & NTRP & 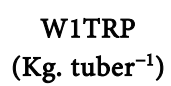 & $\begin{array}{c}\text { WTRP } \\
\left(\text { Kg. } \text { plant }^{-1}\right)\end{array}$ & $\mathrm{Y}\left(\mathrm{t} . \mathrm{ha}^{-1}\right)$ \\
\hline \multirow{4}{*}{ Co } & Yc & $3.50 \pm 0.70^{c}$ & $0.37 \pm 0.07^{\mathrm{h}}$ & $1.25 \pm 0.40^{\mathrm{k}}$ & $12.51 \pm 1.13^{\mathrm{k}}$ \\
\hline & Aa & $3.33 \pm 1.04^{\mathrm{c}}$ & $0.38 \pm 0.07^{\mathrm{h}}$ & $1.32 \pm 0.44^{j}$ & $13.18 \pm 1.86^{\mathrm{j}}$ \\
\hline & Sm & $3.14 \pm 0.68^{c}$ & $0.42 \pm 0.06^{\mathrm{h}}$ & $1.35 \pm 0.38^{j}$ & $13.53 \pm 0.64^{\mathrm{j}}$ \\
\hline & Bo & $3.25 \pm 0.50^{c}$ & $0.46 \pm 0.05^{\mathrm{g}}$ & $1.68 \pm 0.71^{\mathrm{i}}$ & $16.77 \pm 2.90^{\mathrm{i}}$ \\
\hline \multirow{4}{*}{ NPK } & Yc & $4.53 \pm 0.70^{\mathrm{b}}$ & $0.78 \pm 0.12^{\mathrm{f}}$ & $3.55 \pm 0.88^{\mathrm{h}}$ & $35.51 \pm 5.17^{\mathrm{h}}$ \\
\hline & $\mathrm{Aa}$ & $4.53 \pm 0.77^{\mathrm{b}}$ & $0.86 \pm 0.13^{\mathrm{e}}$ & $3.93 \pm 0.81^{\mathrm{f}}$ & $39.32 \pm 3.69^{f}$ \\
\hline & $\mathrm{Sm}$ & $5.06 \pm 0.63^{\mathrm{a}}$ & $0.98 \pm 0.05^{\mathrm{cd}}$ & $4.94 \pm 0.57^{\mathrm{d}}$ & $49.43 \pm 0.89^{\mathrm{d}}$ \\
\hline & Bo & $5.11 \pm 0.67^{\mathrm{a}}$ & $0.96 \pm 0.07^{\mathrm{d}}$ & $5.10 \pm 1.47^{\mathrm{c}}$ & $50.99 \pm 0.00^{c}$ \\
\hline \multirow{4}{*}{ CSA } & Yc & $4.53 \pm 0.70^{\mathrm{b}}$ & $0.78 \pm 0.12^{\mathrm{f}}$ & $3.58 \pm 0.81^{\mathrm{h}}$ & $35.84 \pm 4.68^{\mathrm{h}}$ \\
\hline & $\mathrm{Aa}$ & $4.53 \pm 0.77^{\mathrm{b}}$ & $0.86 \pm 0.13^{\mathrm{e}}$ & $3.94 \pm 0.82^{\mathrm{f}}$ & $39.35 \pm 3.72^{\mathrm{f}}$ \\
\hline & $\mathrm{Sm}$ & $5.06 \pm 0.63^{\mathrm{a}}$ & $0.99 \pm 0.06^{\mathrm{d}}$ & $4.98 \pm 0.60^{\mathrm{d}}$ & $49.81 \pm 1.31^{\mathrm{d}}$ \\
\hline & Bo & $5.11 \pm 0.67^{\mathrm{a}}$ & $1.03 \pm 0.14^{\mathrm{bc}}$ & $5.18 \pm 1.55^{\mathrm{c}}$ & $51.76 \pm 1.14^{\mathrm{c}}$ \\
\hline \multirow{4}{*}{ CSC } & Yc & $4.53 \pm 0.70^{\mathrm{b}}$ & $0.80 \pm 0.10^{\mathrm{f}}$ & $3.73 \pm 0.82^{\mathrm{gh}}$ & $37.26 \pm 5.42^{\mathrm{gh}}$ \\
\hline & Aa & $4.53 \pm 0.77^{\mathrm{b}}$ & $1.06 \pm 0.18^{\mathrm{b}}$ & $4.85 \pm 1.11^{\mathrm{e}}$ & $48.52 \pm 1.55^{\mathrm{e}}$ \\
\hline & $\mathrm{Sm}$ & $5.06 \pm 0.63^{\mathrm{a}}$ & $1.01 \pm 0.05^{\mathrm{cd}}$ & $5.52 \pm 0.89^{\mathrm{b}}$ & $55.17 \pm 2.88^{b}$ \\
\hline & Bo & $5.11 \pm 0.67^{\mathrm{a}}$ & $1.13 \pm 0.07^{\mathrm{a}}$ & $5.83 \pm 1.00^{\mathrm{a}}$ & $58.29 \pm 3.68^{a}$ \\
\hline $\mathrm{F}$ & & 3.69 & 11.63 & 5.47 & 11.14 \\
\hline $\mathrm{P}$ & & $<0.001$ & $<0.001$ & $<0.001$ & $<0.001$ \\
\hline
\end{tabular}

For each parameter, the means followed by different letters are statistically different when $\mathrm{P}<0.05$. NTRP = number of tuberized roots per plant; W1TRP = weight of a tuberized root; WTRP = weight of tuberized roots per plant ; $\mathrm{Y}=$ yield of fresh tuberous root per hectare, CSC: cocoa shells compost, CSA: cocoa shells ash, NPK: chemical fertilizer, Yc: Yacé, Bo: Bonoua, Sm: Six mois, Aa: Alleda agba, Co: control.

higher $(1.13 \mathrm{~kg})$. However, the tuberized roots of the plants in the ash and NPK plots have similar average weights depending on the variety of cassava $(0.99 \mathrm{Kg}$ and $0.98 \mathrm{Kg}$ for NPK and shells ash respectively). Moreover, whatever the cassava variety, fertilization increases yield. However, the Bonoua variety gives the best yield $(58.29$ t) with cocoa shells compost, followed respectively by the Six mois variety $(55.17 \mathrm{t})$, Alleda agba $(48.52 \mathrm{t})$ and finally the Yacévariety $(37.26 \mathrm{t})$.

\subsection{Discussion}

\subsubsection{Chemical Parameters of Composts}

The results of the laboratory analyses showed a difference in the composition of the different fertilizers used. Apart from the high amount of nitrogen in the compost, all other minerals dosed $(\mathrm{P}, \mathrm{K}, \mathrm{Ca}$ and $\mathrm{Mg}$ ) are in low quantities compared to those contained in the cocoa shell ash. This difference could be explained by the mineralization of the organic matter. Indeed, when the shells are reduced to ash, all the organic matter is mineralized. As a result, all the minerals 
constituting the organic matter are released and therefore available in the ash. In compost, only a portion of the organic matter is mineralized by microorganisms during the composting process [23]. The high amount of nitrogen in the compost could be explained by the addition of the leaves of Acacia mangium, a nitrogen-rich legume. This result is consistent with the work of Blanchard et al. [24]. In their work, these authors observed that the nutrient content varied according to the type of organic matter used.

\subsubsection{Physico-Chemical Parameters of Soils}

The chemical analysis of the soils taken from the different sub-plots, are slightly acidic. Fertilized soils generally showed a good cation exchange capacity (CEC) and exchangeable bases are generally higher than controls. This result would be typical for tropical soils and specific to soils with a degrading vegetation cover [25]. Indeed, land in the study area is regularly used for agriculture. As a result, this area is also currently undergoing large-scale deforestation. However, the less dense vegetation cover is exposed to strong evapotranspiration due to the heat of the sunshine and the leaching of unstable ions such as $\mathrm{Na}^{+}$after the rains. This has a negative impact on the physico-chemical parameters of the soils. Thus, cocoa shells compost with a high Cation exchange capacity (CEC) will retain and exchange in large quantities the nutrients readily available to the plant [26].

In addition, the structure of cocoa shells compost will allow a constant renewal of organic matter in the soil. As a result, it constitutes a favorable habitat for the proliferation and nutrition of soil microorganisms, which in turn will mineralize the organic matter and thus make the various nutrients available to cassava plants [26].

\subsubsection{Effect of Treatment-Variety Interaction on Cassava Growth Parameters}

Investigations showed that the application of cocoa shells compost, cocoa shells ash or NPK had a positive effect on the growth parameters of cassava. Indeed, these fertilizers allowed a better evolution of the growth parameters of cassava plants compared to plants in plots without fertilizer. The differences that appeared, such as the difference in stem length, diameter of the stem base, number of leaves, leaf width and length, span between the different treatments of compost or ash and NPK fertilizer compared to the control could be explained by the fact that the crop soils were previously deficient in mineral elements. The application of these fertilizers therefore brought nutrients into the soil solution. The uptake of these mineral elements by the cassava plants contributed to the improved growth and development of cassava. These results are similar to those of Hien et al. [27]. These authors showed in their work that the amounts of nutrients available in the soil for the plants were low. After using vermicompost to fertilize the soil for tomato and cabbage crops, they found an improvement in the growth parameters of these plants compared to the control plants.

For the plots that received fertilizer, cocoa shells compost gave better results 
for cassava plant growth parameters compared to ash and NPK. This variation in the effect of fertilizers on plant growth could be explained by a difference in mineral composition, soil availability and morphology of the cassava plant. Concerning stem length, the cassava variety Six mois gave longer stems. Indeed, it is a dichotomous plant that branches later in its growth from a certain distance from the soil, thanks to a relatively open foliage [28]. This variety uses the mineral elements available in the soil for the growth in length of its stem before it branches, unlike the Bonoua variety, which has a trichotomous branching and branches very early. Furthermore, observation of the stems shows that the Six mois variety has longer internodes. However, internodal growth determines the growth of the stem. The Six mois variety with strong internodal growth gave the longest stems. Stem elongation in this variety is thought to be due to genotype, because in the unfertilized plots, its stem growth was stronger. Stem elongation was decreasing from the Alleda agba and Yacé varieties to the trichotomously branched Bonoua variety. In the latter, poor internodal growth led to the shortest stems. These results are in line with those reported by Djè Bi et al. [29] who noted that the dichotomous variety of cassava gave longer stems than the trichotomous branched variety. In general, the similar results obtained with cocoa shells ash and the mineral fertilizer NPK on growth parameters could be explained by the fact that both types of fertilizers contain the available mineral elements (NPK) and thus directly assimilable by the plant. However, not all of these minerals will be used by the plants for their development. Indeed, during the time of cultivation, part of these elements is used by the plant to ensure its nutritional needs but the other part is lost through leaching. On the other hand, the plants cultivated on the plots fertilized with cocoa shells compost, receive the nutrients gradually and continuously. The slow and progressive mineralization undergone by the compost during the cultivation cycle thanks to the soil microorganisms makes it possible to make the nutrients available to the plant in a progressive manner. This promotes better plant growth, especially of the stem. The stimulation of plant growth remained effective throughout the vegetative stage of the plant. These results are similar to those of Coulibaly et al. [12] who showed during their work on maize cultivation that the compost input increased the length of the stem. The stems of the plants from the fertilized plots had large diameters of the stem base with a predominance of the Bonoua variety. This increase in stem length is the result of diametrical growth. In dicotyledons such as cassava, it occurs after stem elongation and is due to the activity of secondary meristems such as cambium and suberophyllous seating. The latter ensure the growth in thickness of the stem. The activity of these meristems is regulated by the hydromineral and carbon nutrition of the plant. The cocoa shells compost that continuously releases the mineral elements necessary for the nutrition of the plant could ensure the general growth of the plant [23]. Other authors such as Hien et al. [27] had also obtained an increase in cabbage diameter of stem base when using cocoa shells compost. 
The trichotomously branched Bonoua variety also produced the largest number of leaves. This high leaf production is due to the high number of apexes. Indeed, the number of leaves being proportional to the foliation of the stems, the Bonoua variety which has several stems due to its trichotomous ramification has a high number of leaves. Moreover, due to the reduction of internodal growth, the nodes bearing the leaves are brought closer together by increasing the rate of leaf emission and consequently the number of leaves. Therefore, this variety produced more leaves compared to Six mois which has two branches and Yacé and Alleda agba which are single-stemmed varieties. This high number of leaves was observed on maize stalks after application of compost to the crop soil by Coulibaly et al. [12].

The widest and longest leaves were observed in the Bonoua variety when cocoa shells compost is incorporated into the crop soil, but also in all cassava varieties before tuberization. The increase in leaf size during this phase could be explained by the increased activity of the root system which absorbs and transports the minerals released by the compost mineralized by microorganisms [29]. Similar results were obtained by Djé Bi et al. [28] who found significant development of cassava leaves during the aerial development phase of the plant.

Similarly, by its trichotomous branching, the Bonoua variety grown on plots fertilized with cocoa shells compost developed a larger leaf span than the other varieties. The increase in spread is due to the spread-out habit and development of the leaves.

\subsubsection{Effect of Treatment-Variety Interaction on Cassava Yield Parameters}

The increase in the yield of fresh cassava tubers obtained on the fertilized plots would be due to the better growing conditions. Indeed, the different life phases of cassava plants, namely recovery, establishment, development of the aerial system and tuberization, took place on nutrient-rich soil [30]. For example, the roots emitted during the installation will ensure the hydromineral nutrition of the leaves. Through their efficient photosynthetic activity, the leaves will synthesize starch and store it in the roots, thus promoting their tuberization [31]. According to Egle, [32], the increase in the yield of tuberized roots is closely correlated with the development of vegetative variables. This correlation between growth variables and yield at harvest is a reliable indicator for assessing production from plant observations. Knowledge of the vegetative state of the plants at harvest makes it possible to link aerial development to the formation of tuberous roots. This is why the Bonoua variety that showed the best growth of its vegetative organs gave high yields. However, the best yields obtained on plots fertilized with cocoa shells compost are thought to be due to the permanent presence of nutrients in the soil. On these plots fertilized with compost, during the tuberization of the roots, the essential nutrients are made available to the plant for root development through the decomposition action of the humus contained in the compost by microorganisms. The nitrogen contained in these 
fertilizers has contributed to the vegetative development of all the aerial parts of the plant. Similarly, the high level of phosphorus has increased plant resistance. The average number of tuberized roots per plant and the average weight of tubers produced would depend on both the variety and the fertilizer applied to the growing soil. Consequently, the best yields were obtained with the Bonoua variety grown on plots fertilized with cocoa shells compost. The high tuber yield observed in the Bonoua variety is believed to be due to the high number and size of leaves. Also, the leaves can be used as an indicator of good yield. On the other hand, the difference in yield observed between varieties could be due to the difference in volume of their leaf mass. In fact, the number of tuberized roots and their weight would depend on the interception of sunlight by this leaf mass, its photosynthetic activity and the speed of translocation of nutrient reserves from the leaves to the roots. In addition, this leaf density, thanks to the foliar water call, activates the absorption of water and minerals. This enhances the general nutrition of the plant [33]. Also, the spread of the foliage provides shade that creates a microclimate around the cassava stem. This shade helps to conserve soil moisture for root and tuber development [34]. These results are in line with those of Lenis et al. [19] who suggested that the presence of leaves on the stem at harvest could indicate a longevity of these organs that ensure photosynthesis. These authors thus demonstrated that there are strong correlations between leaf life and fresh root yield. The higher yield observed in Bonoua could be attributed to an improvement in soil properties through the structure of the compost and the presence and availability of the nutrient resources it contains [35]. Indeed, during tuberization, microorganisms continue to decompose the compost, thus providing cassava plants with the nutrients essential for their development. This soil becomes more aerated and thus allows the roots to develop well. Similar results were observed by Blakeley and Dennis [36] and, Zhang and Jiang [37]. These authors demonstrated that the resource allocation for each tuber is high when the amount of available nutrient resources is high.

The similar effects observed for cocoa shells ash and NPK would be due to the fact that both types of fertilizers are in the form of minerals directly assimilable by the plant.

\section{Conclusion}

The general objective of this work was to evaluate the effect of organic and inorganic fertilization on the agronomic parameters of cassava. The results obtained showed that fertilizers positively influenced these agronomic parameters. Of the four cassava varieties tested, the Bonoua variety showed the best agronomic potential when grown with cocoa shells compost as fertilizer. Also, this early-branching trichotomous variety has the advantage of increasing the soil cover by its dense foliage and thus reducing the development of weeds in the field while promoting soil moisture conservation. In addition, the use of permanently available cocoa shells would improve cassava productivity at reduced costs and 
conserve soil quality. Thus, the Bonoua variety and cocoa shells compost could be selected to improve cassava yields.

\section{Conflicts of Interest}

The authors declare no conflicts of interest regarding the publication of this paper.

\section{References}

[1] Enete, A.A. and Igbokwe, E.M. (2009) Cassava Market Participation Decisions of Producing Households in Africa. Tropicultura, 27, 129-136.

[2] FAOSTAT (2017) Crop Production in 2014: Cassava Data [Internet]. http://faostat3.fao.org

[3] Howeler, R., Lutaladio, N. and Thomas, G. (2013) Save and Grow: Cassava. Food and Agriculture Organization of the United Nations, Rome, $142 \mathrm{p}$.

[4] FAO (2014) Données de l'alimentation et de l'agriculture. FAOSTAT. http://www.fao.org/faostat/fr/\#compare

[5] Abobi, A.H.D., Angui, T.K.P. and Kouadio, Y.J. (2014) Influence de la fertilisation à base des coques de cacao sur les paramètres chimiques d'un ferral-sol et sur la croissance du maïs (Zea mays L.) à Oumé Côte d'Ivoire. Journal of Applied Biosciences, 82, 7359-7371. https://doi.org/10.4314/jab.v82i1.4

[6] Kitabala, M.A., Tshala, U.J., Kalenda, M.A., Tshijika, I.M. and Mufind, K.M. (2016) Effets de différentes doses de compost sur la production et la rentabilité de la tomate (Lycopersicon esculentum Mill) dans la ville de Kolwezi, Province du Lualaba (RD Congo). Journal of Applied Biosciences, 102, 9669-9679.

[7] N’zué, B., Zohouri, P.G. and Sangaré, A. (2013) Performances agronomiques de quelques variétés de manioc (Manihot esculenta crantz) dans trois zones agro climatiques de la Côte d'Ivoire. Agronomie Africaine, 16, 1-7.

https://doi.org/10.4314/aga.v16i2.1646

[8] Ouédraogo, J., Ouedraogo, E. and Nacro, H.B. (2017) La macrofaune du sol améliore l'efficience de l'utilisation de l'énergie par les microorganismes. Journal of Applied Biosciences, 114, 11345-11356. https://doi.org/10.4314/jab.v114i1.8

[9] Hartmann, M., Frey, B., Mayer, J., Mäder, P. and Widmer, F. (2014) Distinct Soil Microbial Diversity under Improve Soil Fertility and Carbon Storage in Smallholder Banana Farming Systems? Journal of Plant Nutrition and Soil Science, 178, 237-249. https://www.ncbi.nlm.nih.gov https://doi.org/10.1002/jpln.201400281

[10] Kumar, R., Merasenla, A. and Kumawat, N. (2014) Enhancing Crops Productivity and Profitability through Using of Organic Fertilizers. Popular Kheti, 2, 218-221.

[11] Coulibaly, S.S., Kouassi, K.I., Koffi, K.K. and Zoro Bi, I.A. (2019) Effect of Compost from Different Animal Manures on Maize (Zea mays) Growth. Journal of Experimental Biology and Agricultural Sciences, 7, 178-185.

[12] Mankoussou, M., Mialoundama, F. and Diamouangana, J. (2017) Évaluation économique de quelques niveaux de fertilisation du maïs (Zea mays L. variété Espoir) dans la Vallée du Niari, République du Congo. Journal of Applied Biosciences, 11, 10882-10893. https://doi.org/10.4314/jab.v111i1.5

[13] CCC (2017) Évolution de la filière café cacao de 2012 à 2017. Conseil Café Cacao. Journées nationales du cacao et du chocolat $4^{\text {ème }}$ édition des journées nationales du 
cacao et du chocolat Abidjan (JNCC), 60 p.

[14] Riou, G. (1970) Les sols de la savane de Lamto. In: Les caractéristiques du milieu physique: Bulletin Liaison Chercheurs de Lamto $N^{\circ}$ spécial, ( $2^{\mathrm{e}}$ partie), 5-39.

[15] Raffaillac, J.P. (1992) Enracinement de la bouture de manioc (Manihot esculenta Crantz) au cours des premières semaines de croissance. L'Agronomie Tropicale, 46, 273-281. http://www.documentation.ird.fr/hor/fdi:38637

[16] FAO (1980) Les engrais et leurs applications. FAO, Rome, 51 p.

[17] AFNOR (1994) Qualité des sols. Recueil de normes françaises, AFNOR, Paris, 250 p.

[18] Fukuda, W.M.G., Guevara, C.L., Kawuki, R. and Ferguson, M.E. (2010) Selected Morphological and Agronomic Descriptors for the Characterization of Cassava. International Institute of Tropical Agriculture (IITA), Ibadan, $19 \mathrm{p}$.

[19] Daellenbach, G.C., Kerridge, P.C., Wolfe, M.S., Frossard, E. and Finckh, M.R. (2005) Plant Productivity in Cassava-Based Mixed Cropping Systems in Colombian Hillside Farms. Agriculture, Ecosystems and Environment, 105, 595-614. https://doi.org/10.1016/j.agee.2004.08.009

[20] Ambang, Z., Akoa, A., Bekolo, N., Nantia, J., Nyobe, L. and Ongono, Y.S.B. (2007) Tolérance de quelques cultivars de manioc (Manihot esculenta Crantz) et de l'espèce sauvage (Manihot glaziovii) à la mosaïque virale africaine et à la cercosporiose du manioc. Tropicultura, 25, 140-145.

[21] Aniekwe, N.L., Okereke, O.U. and Anikwe, M.A.N. (2004) Modulating Effect of Black Plastic Mulch on the Environment, Growth and Yield of Cassava in a Derived Savanna Belt of Nigeria. Tropicultura, 22, 185-190.

https://www.researchgate.net/publication/258045214

[22] Lenis, J., Calle, F., Jaramillo, G., Perez, J., Ceballos, H. and He, J.C. (2006) Leaf Retention and Cassava Productivity. Field Crops Research, 95, 126-134.

https://doi.org/10.1016/j.fcr.2005.02.007

[23] Sall, M.P. (2014) Étude du compost et du lixiviat obtenue par cocompostage des résidus agroalimentaires à la ferme. Maîtrise en biologie végétale de l'Université de Laval du Québec, Québec, 125 p.

[24] Blanchard, M., Coulibaly, K., Bognini, S., Dugué, P. and Vall, E. (2014) Diversité de la qualité des engrais organiques produits par les paysans d'Afrique de l'Ouest: Quelles conséquences sur les recommandations de fumure. Biotechnologie, Agronomie, Société et Environnement, 4, 512-523.

[25] Igue, A.M., Saidou, A., Adjanohoun, A., Ezui, G., Attiogbe, P., Kpagbin, G., Gotoechan-Hodonou, H., Youl, S.T., Pare, T., Balogoun, I., Ouedraogo, J., Dossa, E., Mando, A. and Sogbedji, J.M. (2013) Evaluation de la fertilité des sols au sud et centre du Bénin. Bulletin de la Recherche Agronomique du Bénin, 12-23.

[26] Carrier, A. (2003) Que se passe-t-il dans le sol? Serriculture maraichère biologique. Agriculture, Pêcherie et Alimentation, $12 \mathrm{p}$.

[27] Hien, V., Ehouman, N.M., Touré, M. and Tiho, S. (2018) Effets du vermicompost à base de coques de cacao et de graminées sur quelques paramètres agronomiques de la tomate du concombre et chou à Yamoussoukro. Journal of Applied Biosciences, 126, 12707-12716. https://doi.org/10.4314/jab.v126i1.8

[28] Djè Bi, I.R., Kouassi, K.I., Koffi, K.K., Kouakou, K.L., Baudoin, J.P. and Zoro Bi, I.A. (2018) Evaluation of Cassava Varieties for Weed Tolerance Ability. Experimental Agriculture, 54, 443-451. https://doi.org/10.1017/S0014479717000151

[29] UIFA (2000) Fertilisants et qualité des produits alimentaires. Union des Industries 
de la Fertilisation Azotée, Paris, 4 p.

[30] El-Sharkawy, M.A. (2003) Cassava Biology and Physiology. Plant Molecular Biolo$g y$, 53, 621-641. https://doi.org/10.1023/B:PLAN.0000019109.01740.c6

[31] Raffaillac, J.P. (1995) La fertilité en zones tropicales humides et le manioc. In: Pichot, J., Sibelet, N. and Lacoeuilhe, J.-J., Eds., Fertilité du milieu et stratégies paysannes sous les tropiques humides, Thème II: Système de culture et objectifs paysans, CIRAD, 286-298.

[32] Egle, K. (1992) Etude de la variabilité des composantes du rendement du manioc (Manihot esculenta Crantz, var. 312-524) en fonction de la fertilité du sol. Mémoire 91-08 d'Ingénieur Agronome: Ecole Supérieure Agronomique de l’Université du Bénin, Lomé, ORSTOM, laboratoire d'agronomie, $111 \mathrm{p}$.

[33] Veltkamp, I.J. (1985) Physiological Causes of Yield Variation in Cassava (Manihot esculenta Crantz). Agricultural University Wageningen Papers, 85, 87-92.

[34] Lahai, M.T., Ekanayake, I.J. and George, J.B. (2003) Leaf Chlorophyll Content and Tuberous Root Yield of Cassava in Inland Valley. African Crop Science Journal, 11, 107-117. https://doi.org/10.4314/acsj.v11i2.27523

[35] Ogundare, K., Agele, S. and Aiyelarie, P. (2012) Organic Amendment of an Ultisol: Effect on Soil Properties, Growth, and Yield of Maize in Southern Guinea Savanna Zone of Nigeria. International Journal of Recycling Organic Waste in Agriculture, 1, 1-7. https://doi.org/10.1186/2251-7715-1-11

[36] Blakeley, D. and Dennis, D.T. (1993) Molecular Approaches to the Manipulation of Carbon Allocation in Plants. Canadian Journal of Botany, 71, 765-778.

https://doi.org/10.1139/b93-088

[37] Zhang, D.Y. and Jiang, X.H. (2000) Costly Solicitation, Timing of Offspring Conflict, and Resource Allocation in Plants. Annals of Botany, 86, 123-131.

https://doi.org/10.1006/anbo.2000.1164 